\title{
Preventing Terrorism Through Early Childhood Education in Indonesia: A Policy Analysis
}

\author{
Cecep Somantri ${ }^{1, *}$ Yohan Rubiyantoro ${ }^{1}$
}

\author{
${ }^{1}$ School of Education, The University of Nottingham, Nottingham, England \\ *Corresponding author. Email: Cecep.Somantri@nottingham.ac.uk
}

\begin{abstract}
Terrorism prevention is often focused on adolescents, even though it is true that the use of children in terrorist acts is a global issue. Few studies do discuss the prevention of terrorism in early childhood, a critical phase or golden age that is instrumental in the formation of a child's character. This research is a case study that is developed based on the emergence of nursery books in Indonesia containing radical words, such as "bomb", "jihad", "bantai" (slaughter) which have been the subject for developing the Anti-Violence Movement at School policy. It is a policy analysis that aims to provide critical input for policy improvement, which is especially pertinent given the lack of existing research on the subject matter in Indonesia. The data are analysed using Bell and Stevenson (2013) framework for policy analysis, which has four analytical themes concerning the translation from policy development to enactment. Based on the analysis, it is found that terrorism prevention through early childhood education (ECE) policy in Indonesia is vague in its meaning and objectives, as well as fails to define the basic notion of "terrorism" itself. The government expects the policy to be a community-led movement, but it turns out that the implementation is still characterised by a top-down approach. At the enactment phase, ECE centres see no urgency in integrating the policy with their centre's vision and mission, because they believe that the policy will not last sustainably at its operation. Surprisingly, the government does not provide any specific training for teachers, nor the budget to implement the policy.

Keywords: Indonesia, terrorism, early childhood education
\end{abstract}

\section{INTRODUCTION}

Terrorism is a real threat to most countries. This has been a global concern for the last few decades. Data from Institute for Economics \& Peace (IEP), published in the Global Terrorism Index (GTI) 2016, shows there were 12,089 terrorist attacks worldwide, in which 29,376 people died (IEP, 2016). Terrorism flourished during the mid-20th century and has become a worldwide issue since the tragedy at World Trade Center (WTC) in New York on September 11, 2001, which killed 3,000 people. In Organisation for Economic Cooperation and Development (OECD) member countries, deaths from terrorism increased dramatically from 77 deaths in 2014 to 577 casualties in 2015, a rise of 650 percent. What's more, 2015 was the worst year for terrorist activity in OECD countries since the September 11 attacks. A total of 21 states from 34 OECD countries experienced a terrorist attack with casualties. Indonesia, as one of those member countries, is an example of a hotbed country for terrorism. GTI 2016 ranked Indonesia as 38th out of 163 countries when it comes to the threat of terrorism (IEP, 2016).

Indonesia is also one of eight countries included in the Countering Violent Extremism Global Survey 2016, alongside the US, UK, France, India, China, Turkey, and Egypt. The survey was administered to 8,000 participants, and the results show that terrorism ranks second after corruption as a source of concern in Indonesia. However, as many as 50 percent of respondents said the threat of terrorism increased, whereas only 18 percent of respondents said that the threat has subsided (Center for Strategic and International Studies (CSIS), 2017). Tempo (2016) used data from the Center for the Study of Terrorism and the Social Conflict University of Indonesia to show that from 2000 to 2015 there were more than 260 cases of terrorism in Indonesia and over 1,000 actual terrorists. The National Agency for Combating Terrorism (Indonesian: Badan Nasional Penanggulangan Terorisme, abbreviated as BNPT) shows that 14 out of 33 provinces in Indonesia are hotbeds for the spread of terrorist ideology. The Institute for Policy Analysis of Conflict (IPAC) (2014) have shown that the Bali bombing was the most frightening act of terror in Indonesia. The bombing killed 202 people and injured 300 . Although the Indonesian government has caught many terrorists, terrorist acts have not stopped and terrorist networks continue to engage in new measures to spread radicalism.

The head of BNPT and the Indonesian Child Protection Commission (Indonesian: Komisi Perlindungan Anak Indonesia, abbreviated as KPAI) said that young children have now become the target for terrorist networks. Terrorist have begun to indoctrinate radical notions not only to adults but also to little children (The Strait Times, 2016). KPAI (2016) revealed during 2016 there were 180 cases or reports of children being exposed to radical ideology and terrorism. More evidence stems from Minister of Education and 
Culture (MoEC) in the Republic of Indonesia, who in 2015 found a book used by an early childhood school in the Depok region which contained the words "bantai" (kill with violence), "bazoka" (bazooka), "peluru" (bullets), "gegana" (Indonesian Special Bomb Detention Unit) alongside other words inciting violence (Tempo, 2016). The MoEC and some community organisations consider these books to be part of an agenda to instil radical ideology into children from an early age. Young children will read this book over and over again until it is embedded in their subconscious. What's more, the BNPT have also shown that the perpetrators of terror spread the notion of violence through social media. In 2016 they were distributing videos of underage children trained to shoot and attack (The Strait Times, 2016).

In response to the spread of radicalism and extremism, the government stopped the circulation of books that contain radical words from early childhood schools across the nation. This was embodied in the Regulation of the Director General of Early Childhood and Community Education. What's more, MoEC (2015) carried out the Anti-Violence Movement at School (Indonesian: Gerakan Anti Kekerasan di Sekolah/GAKS) initiative, a national policy that aims to combat various cases of violence in schools, including the spread of radicalism. This policy is carried out through the inclusion of nationalism values in the form of character education workshops, a requirement for schools to sing national anthems at the beginning and end of the teaching and learning process and training teachers to counter radicalism. This policy is binding on local governments across Indonesia to ensure that there the spread of of violence in schools comes to an end and starts from early childhood. At the implementation level, this policy also requires schools to create a safe and enjoyable school environment for students, one free from exposure to radicalism and violence.

\section{LITERATURE REVIEW}

The literature review presented in this section focuses around three significant terms, namely: policy, terrorism, and early childhood education (ECE). The discussion of these three terms will be divided into two. Firstly, a general debate regarding the three concepts. Secondly, an elaboration on their relevance to the Indonesian context. The discussion will be preceded by a literature review on policy and current debates in policy analysis. This will be followed by a review of literature on terrorism, before finally a discussion on ECE in Indonesia.

\subsection{Policy and Policy Analysis}

Policy has an essential role in everyday life. According to Knill and Tosun (2012), policy is a set of programs designed to achieving goals, values and practices that are predefined. Bell and Stevenson (2013) argue that policy is a series of actions, programs and guidelines proposed by a person, group, and government to achieve a particular goal. Hudson and Lowe (2009) explain more deeply that policy refers to a decision of an organisation that is intended to overcome particular problems or to achieve specific goals that contain provisions that can be used as a guideline for policymakers. Marsh and Smith (2000) say that policy is often defined as a 'product' or 'outcome' designed to address a particular issue. But Considine (2005) mentions there are consequences that arise when we only see public policy as a product. Dye (1992) says the policy may refer to whatever government does or does not choose to do.

\subsection{Terrorism}

Silke (2009) argues that terrorism has evolved over a number of centuries. The world has drafted regulations on the handling of terrorism since 1937 Convention for The Prevention and Suppression of Terrorism. The convention states that terrorism is a crime against the state. Then, in 1977, the European Convention on The Suppression of Terrorism (ECST) emerged, which defined terrorism more broadly as an act which was initially interpreted as a crime against the state and a crime against humanity. However, terrorism is a term that is difficult to define, even though it can be perceived with reference to its real-world characteristics. CSIS (2017) states that each country has its views on those acts classed as terrorist acts and those that are not, meaning that there can be no one definition that can cover all kinds of terrorism that have occurred over the history of humankind.

Ghosh, Chan, Manuel and Dilimulati (2017) define terrorism as the use of terror as a symbolic act designed to influence policy and political behaviour in extraordinary ways and involves the use of threats, terror and violence.

\subsubsection{The rise of child terrorists}

Current debates about terrorism focus on the use of children in terrorist acts. This child exploitation is not a new issue, but groups like ISIS, Bako Haram, and the Pakistani Taliban are increasingly using children to launch their attacks (Bloom \& Horgan, 2015). Meehan and Meehan (2019) assert that children are more easily indoctrinated and find it difficult to resist because they do not understand what is happening to them. Also, children are not as suspicious, so the terrorist will have a higher chance of success if using a child. We can see evidence that terrorists are using children in their acts from a 15 January 2015 video that appeared on the internet, which depicted a 10-year-old child using a gun and killing two Russian members of ISIS suspected of being spies. ISIS claims the video belongs to them. A few days later, twin suicide bombing in northern Nigeria involved three girls under ten years old, who used detonated explosives. Thus, we can see that terrorists have begun training young children to be used as weapons and in wars (Bloom \& Horgan, 2015). 


\subsection{Early childhood}

Early Childhood Education (ECE) is a critical stage of primary education. Countries around the world have pledged that by 2030 all young girls and boys will receive early childhood education that is of good quality (United Nations Educational, Scientific and Cultural Organization (UNESCO), 2015). Parker (2013) considered early age as a time full of important events and a time that laid the foundation for adulthood. Moss and Pen (2003) argue that ECE is primarily designed to facilitate the growth and development of children as a whole by emphasising the development of all aspects of the child's personality.

UNESCO (2016) defines ECE as a period from birth to eight years old, a time when children experience remarkable growth. In this period, children are profoundly influenced by the people around them and by their environment. Similarly, Owen and Haynes (2010) suggest that ECE includes programs that serve children from birth to eight years old and which are designed to improve their intellectual, social, emotional, linguistic and physical development.

Hamiel, Wolmer, Pardo-Aviv, \& Laor (2017) say terrorists recruit children because they have not been able to think critically, so they tend to accept whatever things are taught to them. Children are imitators; they will imitate what they hear and see. They found that a child could imitate or copy a violent act up to six months after the first observation, even if the actions are no longer demonstrated.

\subsection{Terrorism in Indonesia}

The deadliest act of terrorism in Indonesia was the Bali bombing tragedy, which took place on October 12, 2002, and which killed 202 people and injured 300. The action was later followed by a bombing at the JW Marriott hotel, Jakarta, on August 5, 2003, which killed 12 people and wounded 150. Both acts of terrorism are considered to be the worst terrorist events in Indonesia's history (BBC Indonesia, 2011). Sunusi (2011) said that the terrorism movement in Indonesia has existed since 1950. In that era, Darul Islam (DI), an extremist group, was established. They rebelled against The Republic of Indonesia (NKRI) and fought for the establishment of an Islamic State of Indonesia. DI considered their movement as a jihad because the Indonesian government did not enforce Islamic shari'a. This group later developed into Komando Jihad, which in 1976 blew up places of worship. Then, in 1977, came the Indonesian Muslim Liberation Front, which had the same mission to transform Indonesia's republic into an Islamic state (Mubarak, 2008). Wahid (2004) said that from 1985 to 1991, hundreds of terrorist cadres in Indonesia went to Afghanistan to attend military training. The "Afghan alumni" then returned to Indonesia and formed a new group, Jamaah Islamiyah (JI). The group then carried out a bombing on Christmas Eve, December 24, 2000 which killed 16 people and injured 96 others, the Marriott bombing, and several other significant acts of terrorism.
As Tempo (2016) describes, the Indonesian government established a unique board that handles terrorism, namely the National Agency for Combating Terrorism (abbreviated BNPT) in 2010. BNPT is an important institution, because it is structurally directly under the President and the head of BNPT has the same rank as a minister. Between 2010-2013 BNPT arrested 840 perpetrators of terrorist attacks in Indonesia, during which 60 people were shot dead. However, the large-scale arrests of terrorists did not diminish the influence of their respective movements. The terrorist cells of the Jemaah Islamiyah terrorist group for example still conducted terrorist activities in various areas, including Aceh, Jakarta and Poso, which are the hotbeds for terrorism.

This research is a case study on the prevention of terrorism through ECE in Indonesia. The study seeks to answer the research question with primary data, namely in-depth interviews. Before conducting the interviews, the researchers performed a comprehensive literature review to uncover information on relevant previous research, as well as to provide a framework for the importance of the study. This chapter consists of an explanation on the case study methodology, qualitative research, data collection, participants, data analysis, and the process of ethical review.

\section{METHODOLOGY}

This research is a case study on the prevention of terrorism through ECE in Indonesia. The study seeks to answer the research question with primary data, namely in-depth interviews. Before conducting the interviews, the researchers performed a comprehensive literature review to uncover information on relevant previous research, as well as to provide a framework for the importance of the study. Bell and Stevenson's (2013) framework for policy analysis is employed in the study.

\section{FINDINGS AND DISCUSSIONS}

\subsection{The Ideological Debates of GAKS}

Define abbreviations and acronyms the first time they are used in the text, even after they have been defined in the abstract. Abbreviations such as IEEE, SI, MKS, CGS, sc, $\mathrm{dc}$, and rms do not have to be defined. Do not use abbreviations in the title or heads unless they are unavoidable. Ideological debates behind policy formulation are usually based on one of three perspectives; historical, political and bureaucratic. Some questions that arise in the discussions are generally, why the policy was made? And who are the policy actors involved in the policy? (Rizvi \& Lingard, 2010). This section will discuss the findings with these two questions in mind. 


\subsubsection{Background for developing the policy}

The GAKS policy was developed because the case of radicalism and terrorism has become a serious problem in Indonesia and children are increasingly becoming an object of interest for the perpetrators of terror.

"Terrorists now target children as followers of their radicalism and ideology. Even in Indonesia, radicalism has entered the age of Early Childhood Education (PAUD). In Depok, we found a book for kindergartens with radical language. In fact, this is a worldwide phenomenon " (Head of BNPT Speech, 2015)

This statement is a response to the evidence found by the Minister of Education and Culture of the Republic of Indonesia in 2015. The Minister found a book used by an early childhood school in Depok area containing the word "kill", "bazookas", "bullets", "gegana" (Indonesian Special Bomb Detention Unit), and some other words that contain elements of violence. Ministries and some community organisations consider these books to be one of the ways that radical ideology is installed in children from an early age.

This is an international problem, though. When talking academic participants, cases involving children in acts of terrorism in Syria and Damascus were discussed:

"Terrorists are beginning to train children how to fight. They crammed children with radicallymotivated learning media that could potentially cultivate the ideology of radicalism. In Indonesia, children of early childhood have been exposed to radical understanding within their school environment, where the teacher is a jihadist and radical Islamist "(Interview Academic, 2018).

The policy of preventing terrorism in Indonesia through GAKS was developed because of the international demand that children should be protected from all sorts of fears and terror. The UN Convention has mandated that children should be protected against violent acts, including the indoctrination of radicalism and terrorism (UNESCO, 2012). GAKS is also motivated by the Law Number 35 Year 2014 on Child Protection (Pemerintah Republik Indonesia, 2014). The central message of the Act is that children should be protected from all forms of threat and must have access to safe and comfortable education and health services.

"Prevention of terrorism through early childhood is also a response to anti-terrorism laws that provide penalties for parents, teachers and state organisers involving children committing criminal acts of terrorism" (Interview Policy Maker, 2018).

Based on the discussion above, it can be argued that GAKS is a policy to respond to a particular issue (Harman, 1984). Also, the finding proves that it is an evidence-based policy because it is developed on the basis of evidence from the field, which in this case is a radical book used by nursery children. Findings also showed that GAKS developed as a response to the global phenomenon of children being used in acts of terrorism. So, ideological debates on this policy are part of the policy process.

\subsubsection{GAKS policy objectives}

Press releases from the Minister and news articles explain that GAKS has four objectives. First it seeks to protect the child from acts of violence that occur in school. Second, to prevent children from acts of violence in schools. Third, fostering harmonious school conditions between students, teachers, parents and the community. Fourth, creating a safe, comfortable and enjoyable learning process. The GAKS policy was born after the emergence of several terrorist threats. However, when translated more explicitly into policy guidelines, the objectives shift into broader issues, not only violence in the form of terrorism threats, but also bullying, violence, verbal violence, and various other violent matters. Academics states that GAKS' targets are very broad, indeed, Minister of Education Regulation No. 82 of 2015 on GAKS states that GAKS policy targets are students, teachers, school administrators, parent, school committee, community, local government and central government. The specialist program at MoEC says the GAKS policy is unambiguous and detailed. The policy regulates the prevention of violence, countermeasures and sanctions.

"The GAKS policy also details the responsibilities of MoEC, local government and schools. Even the policy regulates the provision of a call centre complaint in each region," (Interview Programme Specialist, 2018)

The interview with the academic showed that the development of GAKS policy is no more than a ceremonial process, because the government does not provide a clear definition of violence. However, it is essential to equate the perspective of all stakeholders.

"Violence is a very broad concept; it can be many things including violence, terror, terrorism, bullying, fighting, verbal violence, harassment. Many things," (Interview Academic, 2018)

Based on this finding, there is a serious issue over the clarity of the definition within the GAKS policy. Without a precise definition, stakeholders will find it difficult to enforce this policy. There will also be enormous potential for bias in the field when translating this policy.

\subsection{The Articulation of GAKS in Organisational Principles}

Once the parameters and priorities of the policy are established, then the policy is delivered to the organisation or institution implementing the policy in the field. In the context of GAKS, performing organisations are schools, especially ECE schools. At this level, the policy is articulated by the school principal or school manager. Articulation of the policy can be seen in the form of policy influence or changes in vision and mission in schools, and 
activities held in schools to support the policy. This section will describe the findings with these two factors in mind.

\subsubsection{The Influence of GAKS on a school's vision and mission}

Based on interviews with principals and teachers, GAKS does not have much impact on the vision and mission of schools. Although GAKS is a national policy, the ECE school does not change their vision and mission, because according to them, in the regulation there is no order to change schools the vision and mission. The principal said GAKS only strengthens the prevention of violence and terror in schools.

"This movement is to remind teachers that the potential for violence and the threat of terror to children is getting bigger in school. But our school mission vision already contains values of tolerance, compassion, character education that is essential to prevent violence and terrorism to children." (Interview Principal, 2018)

Teachers also saw no urgency in changing the school's vision and mission to adapt to GAKS policies. The principal says the policy from the Minister could be changed or terminated anytime, depending on the political situation.

These findings suggest that GAKS as an external policy does not provide any pressure on stakeholders, especially principals and teachers. This finding is different from that of Bell and Stevenson (2013), who said that often policy offers pressures to education stakeholders. But this is not surprising because the government hopes that this policy is not a top-down policy, but instead a movement that comes from the community, even though MoEC has a vital role in the formulation of this policy. Also, local government systems in Indonesia make it difficult for the central government to put on pressure, since Indonesia has embraced the decentralisation of education. This impacts the school, who are now subordinates of the local education authorities, not central government (MoEC). So, the MOEC cannot pressure or sanction the school directly. The principle acknowledges the growing threat of terrorism on children; he sees children today as being susceptible to messages that contain radicalism from online sites, online games, as well as social media.

"As a principal, I am concerned about the potential threat of terrorism to ECE children. I see on YouTube, young children become radical or even join militant groups through solicitation in social media. Terrorists use social media as a tool for propaganda, But I see the government has not focused on underpinning this issue." (Interview Principal, 2018)

It appears then that the policy needs strong political commitment from central government, because the principal is afraid to adjust their program because the policy could be terminated when there is a new presidential cabinet or when a new minister of education and culture is chosen.

\section{CONCLUSIONS AND RECOMMENDATIONS}

\subsection{Conclusions}

The template is designed so that author affiliations are not repeated each time for multiple authors of the same affiliation. Please keep your affiliations as succinct as possible (for example, do not differentiate among departments of the same organization). This template was designed for two affiliations.

1) GAKS is a policy designed to respond to cases of violence and radicalism that occur in schools. This policy is a product or outcome. The development of this policy happens because there is an alarming rise in the number school children, especially young children in ECE, becoming the object of interest for terrorists. MoEC found a nursery book that contains radical words, which sparked this debate. Also, this policy is driven by the global trend of children being used in acts of terrorism and international demands that children should be protected from all sorts of fears and terror, as well as the indoctrination of radicalism and terrorism. Furthermore, GAKS was developed with the involvement of a broad range of participants, i.e. teacher associations, local government and non-governmental and religious organisations. GAKS claims to be a policy that seeks to increase public engagement, rather than a top-down government program, but it is still dominated by the MoEC initiative and does indeed tend to be top-down policy. The role of MoEC is still vital when compared with other policy actors.

2) The GAKS policy does not have a specific strategic direction and objectives. This policy emerged as a response to the threats of children being caught up in terrorism. However, when translated more explicitly in policy guidelines, the intentions turn to broader issues, not only in the form of terrorism, but also bullying, violence and other violent problems. GAKS target also become very broad, to involve not only ECE children but those at all levels of education, right up to secondary school students. The government failed to define violence in detail though, so the policy is changed to become very general and widespread to the extent that it is largely ceremonial. Three strategic directions in GAKS (prevention, handling, and sanctions) are also vague because the central government and LEA are not able to give clear penalties. This is not surprising, because the objective and strategic direction are very broad and general.

\subsection{Recommendations}

This study finds a number of weaknesses in GAKS policies. Therefore, further research is required. Based on the conclusions mentioned above, several policies for improving GAKS can be espoused:

1) GAKS needs to redefine the meaning of violence and develop policy goals to be more specific, i.e. the prevention 
of violence against terrorism in early childhood. A more precise definition will make the policy to provide more clarity, increasing the ease with which it can be integrated into policy strategies and priorities.

2) The policy needs more specific guidance for teachers, so that the teacher translates the policy according to the targets originally envisaged. MoEC needs to develop a technical direction from the Director General of ECE and Community Education on how ECE teachers translate GAKS into curricula and lesson plan.

3) The government should create a robust framework for financing and training for teachers. Schools should be provided with financial incentives to conduct terrorism prevention activities in schools and for teacher training specifically on the prevention of terrorism in schools so that they can increase their knowledge.

\section{REFERENCES}

BBC Indonesia. (2011). Terrorism in Indonesia. News available online:

http://www.bbc.com/indonesia/berita_indonesia/2011/0 8/110802_bnpteror.shtml (Accessed on 9 January 2018)

Bell, L., \& Stevenson, H. (2013) Organizing public education. London: SAGE Publications

Bloom, M., \& Horgan, J. (2015). The rise of the child terrorist: The young faces at the frontlines. Foreign Affairs, 1-5

Center for Strategic and International Studies (CSIS). (2017). Views from around the globe: Countering violent extremism. Washington DC.

Considine, M. (2005). Making public policy.

Cambridge: Polity Press.

Dye, T. (1992). Understanding public policy. $\left(7^{\text {th }}\right.$

Edition). Englewood Cliffs, NJ: Prentice-Hall.

Ghosh, R., Chan, W. A., Manuel, A., \& Dilimulati, M. (2017). Can education counter violent religious extremism?. Canadian Foreign Policy Journal, 23(2), 117-133.

Hamiel, D., Wolmer, L., Pardo-Aviv, L., \& Laor, N. (2017). Addressing the needs of preschool children in the context of disasters and terrorism: Clinical pictures and moderating factors. Current psychiatry reports, 19(7), 38 .

Harman, G. (1984). Conceptual and theoretical issues. In J.R. Hough (ed.) Educational Policy: An International Survey. London: Croom Helm, 13-27. http://unesdoc.unesco.org/images/0024/002457/245728 E.pdf [accesed:11 January 2018].
Hudson, J., \& Lowe, S. (2009). Understanding the policy process, 2nd Edition. Bristol: Policy Press

Institute for Economics \& Peace (IEP). (2016). Global terrorism index 2016, Measuring and Understanding the Impact of Terrorism. Maryland: IEP

Institute for Policy Analysis of Conflict (IPAC). (2014). Countering violent extremism in Indonesia: Need for a rethink. Jakarta.

Knill, C., \& Tosun, J. (2012). Public policy: A new introduction. Basingstoke: Palgrave Macmillan.

LIPI. (2013). Regulation of the Head of Indonesian Science Institute Number 08/E/2013 Regarding Code of Conduct for Scientific Research and Publication. Jakarta. Available from:

http://pusbindiklat.lipi.go.id/wp-content/uploads

Marsh, D., \& Smith, M. (2000). Understanding policy networks: Towards a dialectical approach. Political Studies, 48, 4-21.

Meehan, C., \& Meehan, P. (2019). Exploring the role of 'RE'in early childhood education and care as a response to the PREVENT agenda in England. Early Child Development and Care, 189(7), 1174-1188.

Minister of Education and Culture (MoEC). (2015). National Gross Enrolment Rate for ECE, Primary, and Secondary Schools. Centre for Education Data and Statistic. Jakarta: Minister of Education and Culture. Available from:

http://publikasi.data.kemdikbud.go.id/uploadDir/isi_CA D096D8-E9E1-4E73-8378-9546FF974E12_.pdf [accesed: 2 January 2018].

Minister of Education and Culture (MoEC). (2015). Regulation Number 82 Year 2015 on Preventing Violence at School and Education Institution. Jakarta: Minister of Education and Culture

Minister of Education and Culture (MoEC). (2016). Regulation Number 137 Year 2014 regarding to Early Childhood Education Standard. Jakarta: Minister of Education and Culture. Available from: http://jdih.kemdikbud.go.id/new/public/produkhukum [accesed: 28 December 2017].

Moss, P., \& Pen, H. (2003) Transforming Nursery Education. London: Sage Publication.

Mubarak. (2008). Geneologi islam radikal di Indonesia. Jakarta: Pustaka LP3ES. 
Organisation for Economic Co-operation and Development (OECD). (2016). Education at a Glance 2016: OECD Indicators. Paris: OECD Publishing. Available from: http://dx.doi.org/10.1787/eag-2016-en [accesed: 5 January 2018].

Owen, S., \& Haynes, G. (2010). Training and workforce issue in the early years. In: Pugh, G. and Duffy, B. (eds), Contemporary Issues in the Early Years. $5^{\text {th }}$ ed. London: Sage.

Parker, I. (2013). Early development: Bridging the gap between evidence and policy in early education. London: IPPR.

Pemerintah Republik Indonesia. (2014). UndangUndang Nomor 34 Tahun 2014 tentang Perlindungan Anak. Jakarta: Pemerintah Republik Indonesia

Rizvi \& Lingard, B. (2010). Globalizing education policy. Abingdon: Routledge

Silke, A. (2009). Terrorist, victims, and society. West Sussex: Wiley Publication

Strait Times. (2016). Indonesia Fights Youth Terrorism. News available online: http://www.straitstimes.com/asia/indonesia-fightsyouth-terrorism [accesed: 30 December 2017].

Sunusi, D. M. (2011). Antara jihad dan terorisme: pandangan syar'i terhadap terorisme, kaidah-kaidah seputar jihad, hukum bom bunuh diri \& studi ilmiah terhadap buku Aku melawan teroris. Pustaka AsSunnah.

Tempo. (2016). Preventing Terorrism. News available online:

https://www.tempo.co/topik/lembaga/150/badannasional-penanggulangan-terorisme-bnpt (Accesed on 7 January 2018)

United Nations Children's Fund (UNICEF). (2001). State of the World's Children. New York: UNICEF

United Nations Educational, Scientific and Cultural Organization (UNESCO). (2016). New horizons: A review of early childhood care and education in Asia and the Pacific. Bangkok: UNESCO. Available from:

Wahid, A. (2004). Kejahatan terorisme. Bandung: Refika Aditama

World Bank. (2015). Early childhood education and development in Indonesia: An assessment of policies using Systems Approach for Better Education Results (SABER). World Bank, Washington, DC. Available from:

http://wbgfiles.worldbank.org/documents/hdn/ed/saber/ supporting_doc/CountryReports/ECD/SABER_ECD_In donesia.pdf [accesed: 15 January 2018]. 